\title{
Modifications of proteins of membrane-cytoskeleton complex and production of reactive oxygen species in erythrocytes cryopreserved with polyethylene glycol
}

\author{
N.G. Zemlianskykh, L.O. Babiychuk \\ Institute for Problems of Cryobiology and Cryomedicine, National Academy of Sciences of Ukraine, \\ Kharkov; e-mail: nzemliansky@gmail.com
}

\begin{abstract}
Protein modifications in the membrane-cytoskeleton complex (MCC) of human erythrocytes, as well as changes in the intensity of reactive oxygen species (ROS) production upon cell cryopreservation with polyethylene glycol (PEG) were investigated. The protein profile of ghosts of erythrocytes frozen with PEG has common features with both the control and cells frozen without cryoprotectant. PEG makes it possible to restrict the structural rearrangements of the main MCC proteins under the effect of extreme factors and to restrain the amount of high molecular weight polypeptide complexes induced by the protein-cross-linking reagent diamide at the control level, in contrast to cells frozen without a cryoprotectant. However, changes related to the protein peroxiredoxin 2 in ghosts of erythrocytes cryopreserved with PEG are also attributed to cells frozen without a cryoprotectant that may be associated with the activation of oxidative processes. This is evidenced by a 10-fold increase in ROS formation in erythrocytes frozen under PEG protection. Thus, upon cryopreservation of erythrocytes with PEG, certain disorders in MCC proteins may be associated with increased formation of ROS, which may contribute to the disorganization of the structural components of MCC and disrupt the stability of cryopreserved cells under physiological conditions.
\end{abstract}

Key words: erythrocyte; membrane; cytoskeleton; protein; reactive oxygen species; cryopreservation; polyethylene glycol.

\section{INTRODUCTION}

Donated blood plays an important role in medicine for restoring oxygen supply to tissues in patients with significant blood loss or severe anemia related to abnormal erythrocytes. The formation of donor blood reserves under hypothermic storage $\left(\sim 4^{\circ} \mathrm{C}\right)$ is limited by a short period during which the cells are able to maintain their physiological properties. The use of ultra-low temperatures (down to $-196^{\circ} \mathrm{C}$ ) increases the storage period of cells up to several years without significant loss of their quality. However, the freeze-thawing processes are associated with injuries of the structure and function of various subcellular components as a result of disturbances in intermolecular bonds in complex ordered systems [1]. To protect cells from extreme factors accompanying (C) N.G. Zemlyanskikh, L.O. Babiychuk the cryopreservation process, endo- and exocellular cryoprotective agents (CPAs), distinguished by their ability to penetrate the plasma membrane, are used. Endocellular CPA glycerol has demonstrated high efficiency upon the low-temperature storage of human erythrocytes that makes it possible to use them for transfusion [2]. However, to prevent osmotic shock of cryopreserved erythrocytes in the bloodstream, glycerol must be previously removed out of the cytosol [2]. This stage is time-consuming and requires special equipment that creates certain problems in the transfusion preparation, especially in cases of extreme urgency. Exocellular substances do not penetrate the membrane, and the CPA removal out of cell suspensions becomes a dispensable step due to a gradual decrease in their concentration in the bloodstream. However, studies on designing 
methods for erythrocyte cryopreservation under the protection of exocellular CPAs still do not guarantee an acceptable level of cell viability under physiological conditions [3, 4].

In particular, polyethylene glycol with a molecular weight of 1500 (PEG) provides high integrity of erythrocytes after freeze-thawing (the hemolysis level is about 2\%), but when cells are transferred to conditions that provide the metabolism reactivation, the hemolysis level increases over time. The instability of such cells can be caused by disturbances in the proteins of the membrane-cytoskeleton complex (MCC) under the freeze-thawing effects. This assumption is based on the fact that MCC proteins play an important role in maintaining the unique shape of cells and ensuring mechanical stability and deformability of erythrocytes in the bloodstream [5]. In addition, it was previously found that in erythrocytes under the influence of PEG [6] and freeze-thawing processes [7] there is a significant decrease in the expression of the surface marker CD44, which may be induced by disturbances of intermolecular interactions in MCC.

The transformation of the properties of cryopreserved erythrocytes can be caused by different reasons. In particular, one of them can be related to changes in the protein composition of MCC as a result of the migration of individual components into the cytosol and, conversely, the association of cytosolic proteins with MCC. Besides, spatial-conformational changes in the structure of macromolecules, which impact the localization of their-SH-groups, can be responsible for cell injuries upon cell freezethawing. Another possibility for the MCC protein transformation under low-temperature effects may be caused by disturbances in subcellular components that are sources of the production of oxidizing radicals. Wherein, $\mathrm{SH}$-groups of proteins can be potential targets for the effect of reactive oxygen species (ROS) with their following oxidation and regulatory consequences for the structural and functional state of MCC components [8].
The aim of the study was to assess the modification of MCC proteins in human erythrocytes under the effect of their cryopreservation with PEG on based the detecting of the level of diamide-induced high molecular weight polypeptide complexes and analysis of changes in the protein profile of erythrocyte ghosts using SDS-PAGE, as well as the study of the intensity of ROS production in erythrocytes after freeze-thawing under this CPA-protection.

\section{METHODS}

All procedures performed on human blood corresponded to the Ethical Standards of the Institutional and National Research Ethics Committee, as well as the 1964 Declaration of Helsinki and its subsequent amendments. The following reagents were used in this work: diamide, phenylmethylsulfonyl fluoride (PMSF), sodium azide $\left(\mathrm{NaN}_{3}\right)$, Tris, HEPES, EDTA, sodium dodecyl sulfate (SDS), $\beta$-mercaptoethanol, Coomassie BB G-250 dye, acrylamide, bis-acrylamide, 2',7'-dichlorodihyd rofluorescein diacetate ( $\left.\mathrm{H}_{2} \mathrm{DCF}-\mathrm{DA}\right)$ ("Sigma", USA), bromophenol blue ("Serva", Germany), PEG 1500 ("Fluka”, USA), TCA, $\mathrm{KCl}, \mathrm{MgCl}_{2}$, $\mathrm{NaCl}, \mathrm{NaH}_{2} \mathrm{PO}_{4}, \mathrm{Na}_{2} \mathrm{HPO}_{4}$ and other reagents made in Ukraine and Russia.

Blood samples. Donor blood was obtained from the Blood Service Center in Kharkiv. Erythrocytes were centrifuged at $1200 \mathrm{~g}$ for 7 min at $20-25^{\circ} \mathrm{C}$, plasma and leukocyte layer were removed. Washing of erythrocytes was performed by three-fold centrifugation in a similar model with a solution containing 150 $\mathrm{mM} \mathrm{NaCl}, 10 \mathrm{mM}$ Tris- $\mathrm{HCl}$ (pH 7.4) (the ratio of cells to solution $\sim 1: 7)$. Washed cells were resuspended in modified Ringer's medium (125 $\mathrm{mM} \mathrm{NaCl}, 5 \mathrm{mM} \mathrm{KCl}, 1 \mathrm{mM} \mathrm{MgCl}_{2}, 1 \mathrm{mM}$ $\mathrm{CaCl}_{2}, 32 \mathrm{mM}$ HEPES (pH 7.4), 5 mM glucose) and served as a control.

Freeze-thawing of erythrocytes in PEG experiments. Erythrocytes were incubated in a medium containing 0.2 M PEG, $0.15 \mathrm{M} \mathrm{NaCl}$, $0.01 \mathrm{M}$ Tris- $\mathrm{HCl}(\mathrm{pH} 7.4)$ for $30 \mathrm{~min}$ at $37^{\circ} \mathrm{C}$ 
(the equilibrium concentration of PEG was close to $0.133 \mathrm{M}$ ). Freezing of samples incubated with PEG and cells incubated in Ringer's medium (negative control) was performed by rapidly immersing in liquid nitrogen $\left(-196^{\circ} \mathrm{C}\right)$. Thawing was performed in a water bath at $37^{\circ} \mathrm{C}$ with vigorous shaking. Erythrocytes frozen-thawed with PEG were centrifuged (5 min, $1200 \mathrm{~g}$ ), the supernatant and destroyed cells were carefully removed. Aliquots of pelleted erythrocytes were resuspended in a solution of $0.133 \mathrm{M}$ PEG, 150 $\mathrm{mM} \mathrm{NaCl}, 10 \mathrm{mM}$ Tris-HCl ( $\mathrm{pH}$ 7.4) to obtain the required cell concentration in each series of experiments.

Incubation of erythrocytes with diamide. Pelleted erythrocytes were resuspended in a CPA medium to a final hematocrit of $10 \%$; erythrocytes frozen-thawed without CPA were resuspended in Ringer's medium. All samples were divided into two parts and one of them was supplemented with diamide to a final concentration of $2.5 \mathrm{mM}$. Erythrocytes were incubated with or without diamide for $1 \mathrm{~h}$ at $37^{\circ} \mathrm{C}$.

Preparation of erythrocyte ghosts. After the completion of the erythrocyte incubation, ghosts were obtained [9]. The cells were lysed at $2-5^{\circ} \mathrm{C}$ with a solution containing $10 \mathrm{mM}$ sodium phosphate buffer (pH 8.0) and 0.1 mM PMSF (the ratio of the cell suspension and solution volumes was $\sim 1: 30$ ), and then centrifuged at $20,000 \mathrm{~g}$ for $10 \mathrm{~min}$ at $4^{\circ} \mathrm{C}$. Washing the ghost from hemoglobin was repeated twice using a lysis medium free of PMSF. Aliquots of pelleted erythrocyte ghosts, which have been incubated with diamide, were dissolved in Sample buffer: $0.05 \mathrm{M}$ Tris-HCl (pH 6.8), 2\% SDS, 20\% glycerol, $0.7 \mathrm{mg} / \mathrm{ml} \mathrm{PMSF}, 0.4 \mathrm{mg} / \mathrm{ml} \mathrm{NaN}_{3}$, $0.01 \%$ bromophenol blue. Samples, which have been incubated without diamide, were dissolved in Sample buffer of the same composition with the inclusion of $5 \% \beta$-mercaptoethanol.

Electrophoresis of ghost erythrocyte proteins. Electrophoresis was performed in a Bio Rad Protein II Multi-Gel Casting chamber in SDS-PAG according to the Laemmli system
[9]. The gradient separating gel corresponded to the concentration of polymerizable substances (acrylamide and bis-acrylamide) 5-20\%. Proteins in the gel were stained with Coomassie BB G-250 at room temperature for 1 hour. Excess dye was washed off with $7 \%$ acetic acid solution. The fraction identification in the gel was controlled by a set of marker proteins (Fermentas life sciences Rage Ruler SM0661, Lithuania). The quantitative assessment of proteins (relative changes in the polypeptide content) was performed using the Gel software (Certificate No. 23683, State Department of Intellectual Property of the Ministry of Education and Science of Ukraine, 12.02.2008, Institute for Problems of Cryobiology and Cryomedicine NASU, Ukraine).

Determination of ROS. Aliquots of cryopreserved cells $(50 \mu \mathrm{l})$, prepared after thawing as described above, were resuspended in a medium containing CPA to a concentration of about 4 . $10^{7}$ cells $/ \mathrm{ml}$ and incubated for 1 hour at $37^{\circ} \mathrm{C}$. Control cells were incubated in a similar manner in Ringer's medium. At the end of the incubation, a $\mathrm{DCFH}_{2}$-DA solution (final concentration 4 . $10^{-5} \mathrm{M}$ ) was added to $50 \mu \mathrm{l}$ of each sample and incubated at $37^{\circ} \mathrm{C}$ for $30 \mathrm{~min}$ in the dark. Then, $250 \mu \mathrm{l}$ of the corresponding media was added, reducing the cell concentration for measuring DCF fluorescence parameters (maximum of excitation/emission wavelength 495/529 nm) by flow cytometry using a FACS Calibur instrument (Becton Dickenson, USA). The data were analyzed using the WinMDI 2.8 software (Scripps Research Institute).

Statistical processing of the results was performed using the Statgraphics plus 2.1 for Windows software package (Statistical Graphics Corp.). Data were presented as $\mathrm{m} \pm$ s.d. (mean \pm standard deviation). The experiments were carried out on the blood of four different donors $(n=4)$. The statistical significance of the differences between the groups was assessed using the Wilcoxon test. At $\mathrm{P}<0.05$, the data were considered statistically significant. 


\section{RESULTS AND DISCUSSION}

The ghost protein of erythrocytes subjected to freeze-thawing without CPA can serve as a negative control of the low-temperature effects on MCC proteins since under these conditions the cells are completely destroyed. Disturbances in MCC related to change in its composition can be detected by electrophoretic analysis of the polypeptide composition in erythrocyte ghosts (isolated MCC) using $\beta$-mercaptoethanol in solubilizing buffer, which restores disulfide bonds between protein subunits and allows obtaining the entire spectrum of individual polypeptides [9]. In the electrophoretic protein profile of the ghosts of frozen-thawed erythrocytes without CPA (Fig. 1A, lane 2) changes were revealed in the band 3 area. A decrease in its relative content is accompanied by the appearance of an additional protein fraction with a lower molecular weight localized between bands 3 and 4.1. A new protein fraction can result from partial proteolysis of macromolecules with a higher molecular weight or the binding of cytosolic proteins to MCC. In addition, the MCC profile of such samples clearly shows a sharp decline in the relative content of proteins with m.w. $\sim 60 \mathrm{kDa}$ and band 8 (Fig. 1A, lane 2), which have recently been identified as catalase and peroxiredoxin [10]. Dissociation of these proteins from MCC may indicate the activation of ROS production in destroyed cells.

Changes in erythrocyte MCC proteins caused by spatial-conformational disturbances in the structure of macromolecules can be detected using the protein-cross-linking reagent diamide. Reacting with the - $\mathrm{SH}$-groups of amino acids, diamide promotes the formation of $-\mathrm{S}-\mathrm{S}-$ bridges between polypeptides and produces high-molecular-weight polypeptide complexes (HMWPC). Changes in the protein structure
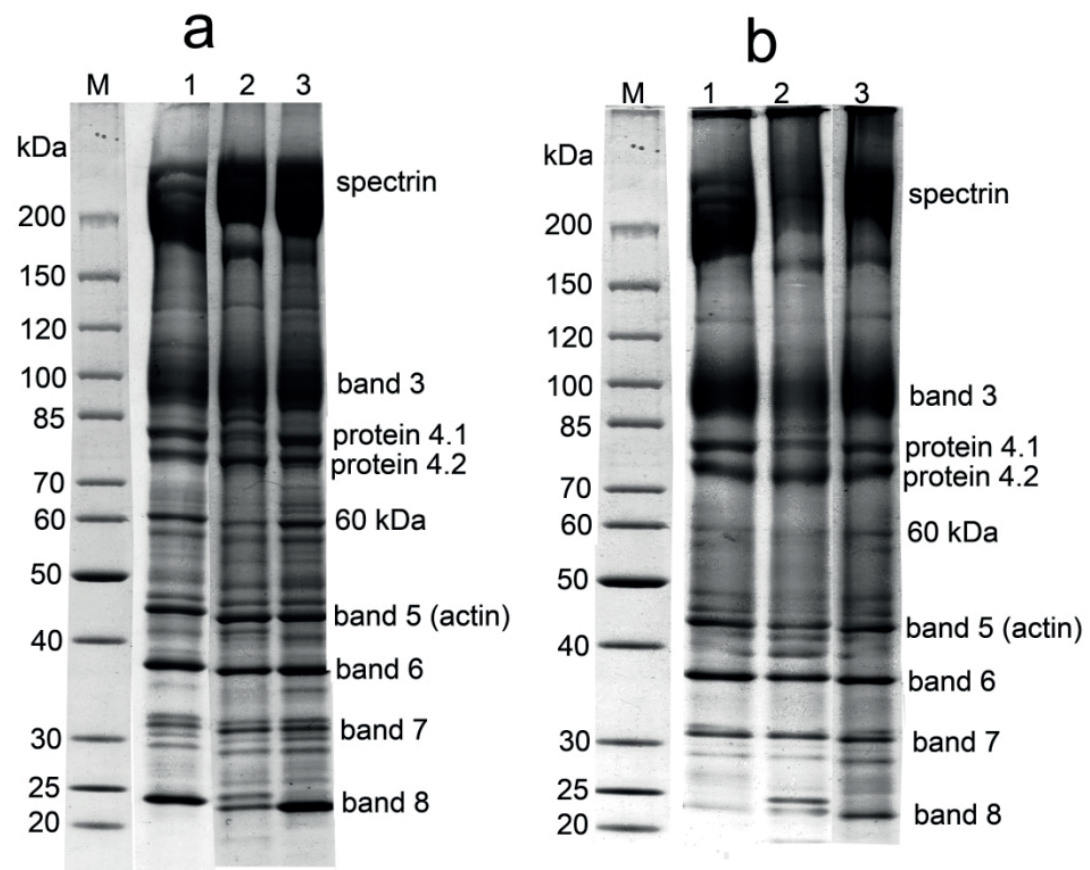

Fig. 1. Distribution of ghost erythrocyte protein fractions in SDS-PAGE under varying electrophoresis conditions. a - SDS-PAGE of proteins of the ghosts erythrocytes, which have not been treated with diamide (performed using $\beta$-mercaptoethanol); $b-$ SDSPAGE of proteins of the ghosts erythrocytes, which have been treated with diamide (performed without $\beta$-mercaptoethanol). $\mathrm{M}$ - protein markers; 1 - control erythrocytes exposed in Ringer-glucose medium; 2 - erythrocytes frozen-thawed without CPA; 3 - erythrocytes frozen-thawed under the protection of PEG (0.2 M). Data from a typical experiment are presented 
determine the accessibility of the "cross-linking" reagent to $-\mathrm{SH}$ groups and consequently the amount of HMWPC. During electrophoresis of ghost erythrocyte proteins, HMWP are concentrated in the starting gel position. In this case, the demand to preserve the $-\mathrm{S}-\mathrm{S}-$ bonds between the components of the HMWPC excludes the use of $\beta$-mercaptoethanol in the solubilizing buffer for the protein preparations.

Under the matched mode of cell exposure with diamide (concentration and duration of incubation) in control erythrocytes, only a small part of MCC proteins was involved in the formation of HMWPC (Fig. 1B, lane 1). Herewith, the emergence of HMWPC was accompanied by a decrease in the levels of spectrin, actin (band 5), and band 3 that was attested by the densitogram data (Table). In addition, we remarked almost complete disappearance of the proteins with m.w. 60 $\mathrm{kDa}$ and band 8 from the protein profile (Fig. 1B, lane 1).

In comparison to the control, in erythrocytes frozen-thawed without CPA and subsequently treated with diamide the level of HMWPC was augmented and accompanied by a decrease in the relative content of the main MCC proteins - spectrin and band 3 (Fig. 1B, lanes 2, Table) that characterizes the increase in the availability of $-\mathrm{SH}$ groups of these proteins for diamide. However, the other protein, namely the band 8 , was revealed in the ghosts of erythrocytes frozen-thawed without CPA upon their treatment with diamide as opposed to its complete absence in the MCC profile of the control cells (Fig. $1 \mathrm{~B}$, lane 2). Although in such a sample, it was present in a smaller amount than in native cells that have not been treated with a cross-linking reagent (see Fig. 1A, lane 1). In addition, we remarked the emergence of an additional protein fraction in the area between bands 3 and 4.1 that was also typical for the MCC profile of erythrocytes frozen-thawed in the absence of CPA and subsequently incubated without diamide (Fig. 1A, lane 2). Another feature of the protein spectrum of MCC erythrocytes frozenthawed without CPA, which has been detected with diamide, was associated with a distinct manifestation of additional protein fractions in the area between bands 5 and 6 . One of the reasons for their manifestation may be the formation of cross-links between some minor polypeptides accompanied by their inclusion in the MCC.

Disturbances in the structure of MCC proteins under the freeze-thawing can be

Changes in the level of individual protein fractions in the MCC of erythrocytes upon their freeze-thawing.

\begin{tabular}{|c|c|c|c|c|}
\hline \multirow[b]{2}{*}{ Protein fractions, $\%$} & \multirow{2}{*}{$\begin{array}{l}\text { Native erythrocytes } \\
\text { (Ringer's solution) }\end{array}$} & \multicolumn{3}{|c|}{ Diamide-treated erythrocytes } \\
\hline & & $\begin{array}{c}\text { control } \\
\text { (Ringer's solution) }\end{array}$ & $\begin{array}{l}\text { Freeze-thawed } \\
\text { without CPA }\end{array}$ & $\begin{array}{c}\text { Freeze-thawed } \\
\text { with PEG }\end{array}$ \\
\hline HMWP & - & $7.4 \pm 0.6$ & $11.7 \pm 0.9 *$ & $9.0 \pm 1.6$ \\
\hline Spectrin & $22.7 \pm 0.6$ & $18.5 \pm 0.8^{\#}$ & $15.6 \pm 1.1^{\# *}$ & $16.3 \pm 1.9^{\#}$ \\
\hline Band 3 & $21.1 \pm 1.4$ & $17.1 \pm 0.9^{\#}$ & $14.4 \pm 1.3^{\# *}$ & $15.7 \pm 1.0^{\#}$ \\
\hline Protein 4.1 & $4.3 \pm 0.6$ & $4.2 \pm 0.9$ & $2.9 \pm 0.4$ & $4.1 \pm 0.6$ \\
\hline Band 5 & $4.8 \pm 0.7$ & $3.4 \pm 0.6^{\#}$ & $3.1 \pm 0.4^{\#}$ & $3.6 \pm 0.4^{\#}$ \\
\hline Band 6 & $4.2 \pm 1.0$ & $2.9 \pm 0.8$ & $2.8 \pm 0.3$ & $3.2 \pm 1.0$ \\
\hline Band 8 & $3.5 \pm 0.6$ & - & $1.3 \pm 0.4^{\# *}$ & $1.5 \pm 0.4^{\# *}$ \\
\hline
\end{tabular}

Note: The content of protein fractions is presented in relation to the total amount of protein in the sample $(\%)$. " The data statistically differ from native erythrocytes not treated with diamide, $\mathrm{P}<0.05, \mathrm{n}=4$. $*$ The data statistically differ from the control erythrocytes treated with diamide, $\mathrm{P}<0.05, \mathrm{n}=4$. 
initiated by changes in three-helical repeating segments of $\alpha$ - and $\beta$-spectrin subunits [11], since some of them are unstable and subjected unfolding even under physiological conditions [11]. Modifications in the structure of spectrin repeats can cause disruptions in the integrity of the entire MCC protein network because several of these segments are involved in the interaction with other proteins $[11,12]$. As a result, membranes of erythrocytes frozen without CPA become unstable and can be fragmented. A similar conclusion can be drawn from the analysis of the electrophoretic profile of ghost proteins of such erythrocytes, when diamide was not used. In the latter case, the observed decrease in band 3 level can be explained by membrane fragmentation accompanied by the loss of integral components.

Analysis of protein profile of the ghost erythrocytes subjected to freeze-thawing under PEG protection did not reveal any significant differences in the distribution of proteins from the control pattern (Fig. 1A, lane 3), when cells were incubated after thawing without diamide. Moreover, the level of diamide-induced HMWPC in such erythrocytes did not differ from the control values (Fig. 1B, lane 3, Table). In addition, the pattern of the ghost protein fraction distribution in erythrocyte frozen under PEG protection and subsequently incubated with diamide was similar to the protein profile of the ghosts of native erythrocytes that were not treated with a cross-linking reagent (compare Fig. 1a, lane 1 and b, lane 3 ). In particular, band 8 can be seen in their protein profile. However, the presence of band 8 in the protein profile of this sample makes it similar to erythrocytes frozen without CPA.

Thus, the protein profile of erythrocytes frozen under PEG protection has common features both with control cells and those that were frozen without CPA. On the one hand, PEG presence in the medium during erythrocyte freeze-thawing made it possible to restrict the structural rearrangements of a band 3 protein and spectrin under the influence of extreme physicochemical factors, for this reason, the HMWPC level did not differ from the control. On the other hand, changes in the MCC protein profile of cryopreserved with PEG erythrocytes associated with band 8 are also characteristic of cells frozen without CPA. Changes in this fraction indicate the involvement of the protein in the control of cell stability and may be associated with the activation of oxidative processes in the cells.

The protein band 8 is peroxiredoxin 2 [10], which takes part in the cell protection from oxidative stress [13]. It contains a functional, readily available - $\mathrm{SH}$-group of cysteine that explains its disappearance from the protein profile of control erythrocytes due to its transition to the HMWPC under the diamide effect. In cases of disturbances leading to an increase in ROS production in cells the peroxiredoxin is the first to respond to them, since-SH groups of other proteins react with hydrogen peroxide $\left(\mathrm{H}_{2} \mathrm{O}_{2}\right)$ several orders of magnitude slower [13]. The oxidation of some peroxiredoxin molecules makes them inaccessible to the diamide effect and allows the detecting of the protein in the electrophoretic profile of ghosts. In addition, the peroxiredoxin presence in the electrophoretic profile of ghosts of erythrocyte frozen-thawed under PEG protection may explain why, despite the high level of cell integrity after freeze-thawing, a significant part of them is destroyed upon metabolism reactivation under physiological conditions. Thus, cell injuries upon freeze-thawing can be caused not only by direct disturbances of the spatial-conformational state of MCC proteins under extreme environmental factors but, possibly, by the alterations of proteins related to oxidative stress.

The development of oxidative processes in the cells is evidenced by an increase in the intensity of ROS production with a reliable indicator reagent $\mathrm{DCFH}_{2}-\mathrm{DA}$. After its penetration into the cell, the reagent is deesterified remaining a non-fluorescent compound $\left(\mathrm{DCFH}_{2}\right)$ until it is oxidized and 
converted to DCF. Thus, the increase in DCF fluorescence, which is characterized by the median value of the distribution histograms, reflects an increase in ROS production in the cells. Ascertainment of ROS in erythrocytes cryopreserved in PEG presence showed a 10-fold increase in DCF fluorescence relative to control (Fig. 2). The average median value of histograms in such samples was $285.4 \pm 71.2$ versus $25.9 \pm$ 3.1 (r.u.) in the control. An increase in ROS production in cells cryopreserved under PEG protection can contribute to disorganization of the MCC structure components and instability of cryopreserved cells upon their return to physiological conditions.

The main source of ROS in erythrocytes is spontaneous autooxidation of hemoglobin resulting in the production of met-hemoglobin and superoxide radical, which under the effect of superoxide dismutase is rapidly converted into $\mathrm{H}_{2} \mathrm{O}_{2}$ [14]. An increase in the concentration of $\mathrm{H}_{2} \mathrm{O}_{2}$ in the cells promotes further hemoglobin oxidation [14] up to the dissociation of heme from the protein part and its covalent transformation [14]. The modified porphyrin ring is capable of interacting by a hydrophobic mechanism with various subcellular components. Despite the fact that met-hemoglobin was not detected

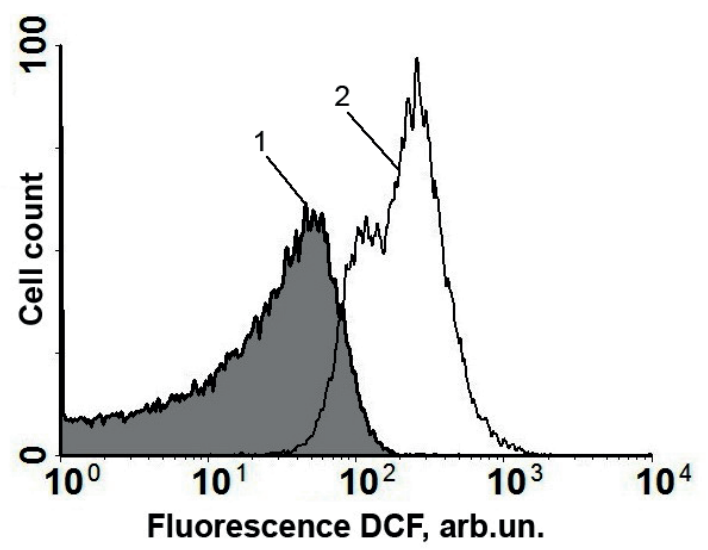

Fig. 2. Change in the intensity of DCF fluorescence in frozenthawed erythrocytes with PEG. (1) - control (gray background of histograms); (2) - erythrocytes frozen-thawed under the protection of PEG $(0.2 \mathrm{M})$. Data from a typical experiment are presented in erythrocytes frozen under the protection of exocellular CPA dextran and trehalose [15], the question on the possibility of the formation of met-hemoglobin or other oxidized forms of this protein in erythrocytes cryopreserved with PEG requires experimental verification. Consequently, the processes of hemoglobin autoxidation cannot be ruled out as sources that activate ROS production in cryopreserved erythrocytes.

In addition, NADPH oxidases (NOX) can play an essential role in ROS formation in erythrocytes frozen-thawed under PEG protection. It was attested in sickle erythrocytes that NOX activity mediated a significant part of ROS production [16]. Ions $\mathrm{Ca}^{2+}$ play a special role in NOX regulation, operating the assembly and functioning of 4 NOX types (out of 5 known ones) found in human erythrocytes [16]. It should be noted that $\mathrm{Ca}^{2+}$ dependent stimulation of NOX in erythrocytes in PEG presence may be caused by $\mathrm{Ca}^{2+}$-ATPase activity inhibition [17] and an increase in $\mathrm{Ca}^{2+}$ level since even in an isotonic medium containing PEG, there was a 10-fold increase in $\mathrm{Ca}^{2+}$ entry into erythrocytes was revealed [18]. Meanwhile, an increase in ROS production can further inactivate $\mathrm{Ca}^{2+}$ ATPase [19] and contribute to disturbances of its regulation by calmodulin [20], which does not allow the cells to adequately respond to signals aimed at controlling the intracellular $\mathrm{Ca}^{2+}$ level. It can be assumed that the intensification of ROS production in erythrocytes upon cryopreservation in $\mathrm{PEG}$ presence can have a significant effect on $\mathrm{Ca}^{2+}$-dependent regulation processes of the structural and functional of MCC components responsible for maintaining cell integrity under stress.

\section{CONCLUSIONS}

The modification of MCC proteins in erythrocytes cryopreserved under PEG protection can be caused not only by the direct action of extreme physicochemical factors accompanying cell freeze-thawing but also by dysregulation 
of protein-protein interactions due to oxidative processes when ROS production increasing. Assuming that changes in erythrocyte MCC include $\mathrm{Ca}^{2+}$-dependent mechanisms of activation of ROS production, it can be expected that the inclusion of pharmaceutically acceptable inhibitors blocking the growth of intracellular $\mathrm{Ca}^{2+}$ level and antioxidants into cryopreservation medium can reduce the negative manifestations of subcellular system disorders in erythrocytes during cryopreservation with PEG.

Finding. The study was carried out within the framework of the budgetary financing of research work No. 2.2.6.90 (state registration No. 0114U0011320) of the National Academy of Sciences of Ukraine.

The authors of this study confirm that the research and publication of the results were not associated with any conflicts regarding commercial or financial relations, relations with organizations and/or individuals who may have been related to the study, and interrelations of co-authors of the article.

\section{Н.Г. Землянських, Л.О. Бабійчук}

МОДИФІКАЦІЇ БІЛКІВ МЕМБРАНО-ЦИТОСКЕЛЕТНОГО КОМПЛЕКСУ ТА УТВОРЕННЯ АКТИВНИХ ФОРМ КИСНЮ В КРІОКОНСЕРВОВАНИХ 3 ПОЛІЕТИЛЕНГЛІКОЛЕМ ЕРИТРОЦИТАХ

Інститут проблем кріобіологї $і$ кріомедицини НАН України, Харків; е-таil: nzemliansky@gmail.com

Досліджено модифікації білків мембрано-цитоскелетного комплексу (МЦК) еритроцитів людини, а також зміни інтенсивності утворення активних форм кисню (АФК) при кріоконсервуванні клітин з поліетиленгліколем (ПЕГ). Білковий профіль в еритроцитах, заморожених з ПЕГ, має спільні властивості як з контрольними клітинами, так і $з$ тими, які були заморожені без кріопротектора. ПЕГ дає змогу обмежити структурні перебудови основних білків МЦК під дією екстремальних факторів і зберегти кількість високомолекулярних поліпептидних комплексів, індукованих білокзшиваючим реагентом діамидом на рівні контролю, на відміну від клітин, заморожених без кріопротектора. Однак зміни, що стосуються білка пероксиредоксину 2, кріоконсервованих з ПЕГ еритроцитів, також характерні для клітин, заморожених без кріопротектора, що може бути пов'язано з активацією окисних процесів. Про це свідчить 10-разове збільшення продукції АФК в еритроцитах, заморожених $з$ додаванням ПЕГ. Таким чином, при кріоконсервуванні еритроцитів з ПЕГ певні порушення білків МЦК можуть бути пов'язані зі змінами утворення АФК, що сприяє дезорганізації структурних компонентів МЦК і порушенню стабільності кріоконсервованих клітин у фізіологічних умовах.

Ключові слова: еритроцит; мембрана; цитоскелет; білок; активні форми кисню; кріоконсервування; поліетиленгліколь.

\section{Н.Г. Землянских, Л.А. Бабийчук}

МОДИФИКАЦИИ БЕЛКОВ МЕМБРАНО-ЦИТОСКЕЛЕТНОГО КОМПЛЕКСА И ОБРАЗОВАНИЕ АКТИВНЫХ ФОРМ КИСЛОРОДА В КРИОКОНСЕРВИРОВАННЫХ С ПОЛИЭТИЛЕНГЛИКОЛЕМ ЭРИТРОЦИТАХ

Исследованы модификации белков в мембрано-цитоскелетном комплексе (МКЦ) эритроцитов человека, а также изменение интенсивности продукции активных форм кислорода (АФК) при криоконсервации клеток с полиэтиленгликолем (ПЭГ). Белковый профиль эритроцитов, замороженных с ПЭГ, имеет общие черты как с контрольными клетками, так и с клетками, замороженными без криопротектора. ПЭГ позволяет ограничить структурные перестройки основных белков МКЦ под действием экстремальных факторов и сохранить количество высокомолекулярных полипептидных комплексов, индуцируемых белоксшивающим реагентом диамидом на уровне контроля, в отличие от клеток, замороженных без криопротектора. Однако изменения, касающиеся пероксиредоксина 2 в эритроцитах, криоконсервированных с ПЭГ, также характерны для клеток, замороженных без криопротектоpa, что может быть связано с активацией окислительных процессов. Об этом свидетельствует 10-кратное увеличение продукции АФК в эритроцитах, замороженных с ПЭГ. Таким образом, при криоконсервировании эритроцитов с ПЭГ определенные нарушения белков МКЦ вероятно связаны с изменениями продукции АФК, что может способствовать дезорганизации структурных компонентов МКЦ и нарушению стабильности криоконсервированных клеток в физиологических условиях.

Ключевые слова: эритроцит; мембрана; цитоскелет; белок; активные формы кислорода; криоконсервирование; полиэтиленгликоль.

\section{REFERENCES}

1. Ragoonanan V, Hubel A, Aksan A. Response of the cell membrane-cytoskeleton complex to osmotic and freeze/ thaw stresses. Cryobiology. 2010;61(3):335-44. 
2. Scott KL, Lecak J, Acker JP. Biopreservation of red blood cells: past, present, and future. Transfus Med Rev. 2005;19(2):127-42.

3. Babijchuk LA, Zemlianskykh NG. Optimization and advantages of washing-out method of erythrocyte cryopreservation with PEO-1500. Probl Cryobiol. 2001;(1):35-41.

4. Singbartl K, Langer R, Henrich A. Altered membrane skeleton of hydroxyethylstarch-cryopreserved human erythrocytes. Cryobiology. 1998;36(2),115-23.

5. Mohandas N, Chasis JA. Red blood cell deformability, membrane material properties and shape: regulation by transmembrane, skeletal and cytosolic proteins and lipids. Semin Hematol. 1993;30(3):171-92.

6. Zemlianskykh NG. Effect of substances with cryoprotective properties on surface marker CD44 in human erythrocytes. Cytol Genet. 2016;50(3):203-13.

7. Zemlianskykh NG, Babijchuk LA. Changes in erythrocyte surface marker cd44 during hypothermic and low temperature storage. Fiziol Zh. 2016;62(2):94-102.

8. Kriebardis AG, Antonelou MH, Stamoulis KE, EconomouPetersen E, Margaritis LH, Papassideri IS. Progressive oxidation of cytoskeletal proteins and accumulation of denatured hemoglobin in stored red cells. J Cell Mol Med. 2007;11(1):148-55.

9. Fairbanks G, Steck TL, Wallach DF. Electrophoretic analysis of the major polypeptides of the human erythrocyte membrane. Biochemistry. 1971;10(13),2606-17.

10. Sharma S, Punjabi V, Zingde SM, Gokhale SM. A comparative protein profile of mammalian erythrocyte membranes identified by mass spectrometry. J Membr Biol. 2014;247(11):1181-1189.

11. Lux 4th. SE. Anatomy of the red cell membrane skeleton: unanswered questions. Blood. 2016;127(2):187-99.

12. An X, Gauthier E, Zhang X, Guo X, Anstee DJ, Mohandas N, Chasis JA. Adhesive activity of Lu glycoproteins is regulated by interaction with spectrin. Blood.
2008;112(13):5212-18.

13. Peskin AV, Dickerhof N, Poynton RA, Paton LN, Pace PE, Hampton MB, Winterbourn CC. Hyperoxidation of peroxiredoxins 2 and 3: rate constants for the reactions of the sulfenic acid of the peroxidatic cysteine. J Biol Chem 2013;288(20):14170-77.

14. Kanias T, Acker JP. Biopreservation of red blood cells the struggle with hemoglobin oxidation. FEBS J. 2010;277(2):343-356.

15. Pellerin-Mendes C, Million L, Marchand-Arvier M, Labrude P, Vigneron C. In vitro study of the protective effect of trehalose and dextran during freezing of human red blood cells in liquid nitrogen. Cryobiology. 1997;35(2):173-86.

16. George A, Pushkaran S, Konstantinidis DG, Koochaki S, Malik P, Mohandas N, Zheng Y, Joiner CH, Kalfa TA. Erythrocyte NADPH oxidase activity modulated by Rac GTPases, PKC, and plasma cytokines contributes to oxidative stress in sickle cell disease. Blood. 2013;121(11):2099-107.

17. Zemlianskykh NG, Babiychuk LA.. The changes in erythrocyte $\mathrm{Ca}^{2+}$-ATPase activity induced by PEG-1500 and low temperatures. Cell Tissue Biol. 2017;11(2):104-10.

18. Kucherenko YV, Bernhardt I. The study of $\mathrm{Ca}^{2+}$ influx in human erythrocytes in isotonic polyethylene (glycol) 1500 (PEG-1500) and sucrose media. Ukr Biokhim Zh. 2006;78 (6):46-52.

19. Osborn KD, Zaidi A, Urbauer RJB, Michaelis ML, Johnsonet CK. Single-molecule characterization of the dynamics of calmodulin bound to oxidatively modified plasma-membrane $\mathrm{Ca}^{2+}$-ATPase. Biochemistry. 2005;44(33):11074-81.

20. Chen B, Mayer MU, Squier TC. Structural uncoupling between opposing domains of oxidized calmodulin underlies the enhanced binding affinity and inhibition of the plasma membrane Ca-ATPase. Biochemistry. 2005;44(12):4737-47.

Received 01.02.2021 